\title{
Emerging new clinical applications for palifermin: beyond its use in oral mucositis and graft versus host disease
}

This article was published in the following Dove Press journal:

Biologics:Targets and Therapy

2 June 2012

Number of times this article has been viewed

\section{Shailendra Kapoor}

Richmond,VA, USA
Correspondence: Shailendra Kapoor

2300 E Cary Street, Richmond,

VA 23223, USA

Email shailendrakapoor@yahoo.com

\section{To the editor}

I read with great interest the recent article by Barasch et al in a recent issue of your journal. ${ }^{1}$ The article is highly thought-provoking. Interestingly, the past few years have seen the emergence of a number of novel clinical applications of palifermin, in addition to its use in oral mucositis and graft versus host disease.

For instance, palifermin gene therapy attenuates the symptoms and enzymatic changes seen in ulcerative colitis, resulting in decreased expression of tumor necrosis factor alpha and increased expression of Ki67 and keratinocyte growth factor receptor, thereby ameliorating the changes in the colon seen in ulcerative colitis. ${ }^{2}$ Similarly, a single application of palifermin before radiation therapy significantly ameliorates radiotherapy-induced functional deterioration in bladder tissue. ${ }^{3}$ In fact, Czibere et al have recently reported successful management of severe hemorrhagic cystitis (that developed as a consequence of stem cell transplantation) with palifermin therapy. ${ }^{4}$

Further, palifermin reduces the duration of dysphagia, as well as the incidence of grade 2 dysphagia, in patients receiving concurrent chemotherapy and radiotherapy for thoracic malignancies, such as advanced lung carcinoma. ${ }^{5}$ Similarly, preadministration of palifermin markedly decreases diarrhea following administration of agents such as irinotecan. ${ }^{6}$

The above examples clearly illustrate the significant immunomodulatory potency of palifermin. Further large-scale studies are needed to elaborate further and investigate fully these potential uses of palifermin.

\section{Disclosure}

The author reports no conflicts of interest in this work.

\section{References}

1. Barasch A, Epstein J, Tilashalski K. Palifermin for management of treatment-induced oral mucositis in cancer patients. Biologics. 2009;3:111-116.

2. Liu CJ, Jin JD, Lv TD, Wu ZZ, Ha XQ. Keratinocyte growth factor gene therapy ameliorates ulcerative colitis in rats. World J Gastroenterol. 2011;17:2632-2640.

3. Jaal J, Dorr W. Effect of recombinant human keratinocyte growth factor (rHuKGF, Palifermin) on radiationinduced mouse urinary bladder dysfunction. Int J Radiat Oncol Biol Phys. 2007;69:528-533.

4. Czibere A, Bruns I, Graef T, et al. Treatment of severe hemorrhagic cystitis after allogeneic stem cell transplantation with palifermin, a recombinant human keratinocyte growth factor. Biol Blood Marrow Transplant. 2007; 13:872-874. 
5. Schuette W, Krzakowski MJ, Massuti B, et al. Randomized Phase II study of palifermin for reducing dysphagia in patients receiving concurrent chemoradiotherapy for locally advanced unresectable non-small cell lung cancer. J Thorac Oncol. 2012;7:157-164.
6. Gibson RJ, Bowen JM, Keefe DM. Palifermin reduces diarrhea and increases survival following irinotecan treatment in tumor-bearing DA rats. Int J Cancer. 2005; 116:464-470.

\section{Publish your work in this journal}

Biologics: Targets \& Therapy is an international, peer-reviewed journal focusing on the patho-physiological rationale for and clinical application of Biologic agents in the management of autoimmune diseases, cancers or other pathologies where a molecular target can be identified. This journal is indexed on PubMed Central, CAS, EMBase, Scopus and the Elsevier Bibliographic databases. The manuscript management system is completely online and includes a very quick and fair peerreview system, which is all easy to use. Visit http://www.dovepress. $\mathrm{com} /$ testimonials.php to read real quotes from published authors. 